\title{
An investigation of a nosocomial outbreak of Clostridium difficile by pyrolysis mass spectrometry
}

\author{
J. T. MAGEE, J. S. BRAZIER, I. K. HOSEIN, C. D. RIBEIRO, D. W. HILL, A. GRIFFITHS, \\ C. DA COSTA, A. J. SINCLAIR* and B. I. DUERDEN
}

Department of Medical Microbiology and Public Health Laboratory and *Acute Care of the Elderly Unit, University Hospital of Wales, Heath Park, Cardiff CF4 4XW

\begin{abstract}
Summary. Isolates from a presumptive nosocomial outbreak of Clostridium difficile infection at a large teaching hospital were typed by pyrolysis mass spectrometry (PMS) and antibiograms. One isolate, from the putative index case, was dissimilar from the outbreak strain, but 24 isolates from 16 patients were indistinguishable by both methods. The outbreak centred on two wards for the acute care of the elderly, with a few cases elsewhere. Transfer of patients appeared to be the route of transmission between wards. There was a significant fall in the incidence of cases following intervention by the Infection Control Unit. This included ward inspection, advice on antibiotic usage and advice on prevention of faecal-oral transfer, particularly by proper handwashing. Subsequent monitoring of $C$. difficile infection showed a background of sporadic, dissimilar isolates with occasional apparent cross-infection incidents limited to a few patients. In suspected outbreaks, patterns of antibiotic susceptibility may be useful in initial screening, before referral for more sophisticated typing. There was excellent correlation between PMS results, antibiograms and epidemiological information.
\end{abstract}

\section{Introduction}

Toxigenic strains of Clostridium difficile cause pseudomembranous colitis (PMC) and antibioticassociated diarrhoea (AAD). ${ }^{1,2}$ Cross-infection may occur, ${ }^{3}$ and outbreaks of nosocomial $C$. difficile AAD, sometimes with cases of PMC, in elderly hospitalised patients have become a major problem in some hospitals. ${ }^{4-7}$ The few methods for typing $C$. difficile are generally complex, expensive, low-throughput techniques limited to a few specialised laboratories. Methods include unmodified SDS-PAGE, ${ }^{8}$ SDSPAGE of ${ }^{35} \mathrm{~S}$-methionine-labelled cultures, ${ }^{9,10}$ immunoblotting of outer-membrane proteins, ${ }^{11}$ serogrouping, ${ }^{12}$ bacteriocin and bacteriophage typing, ${ }^{13}$ and restriction endonuclease fragment length polymorphism analysis. ${ }^{14}$ Antibiograms may also be helpful in typing. ${ }^{13,15}$ Knowledge of the epidemiology of $C$. difficile outbreaks remains limited because of the restricted availability of typing services.

A recent study ${ }^{16}$ of pyrolysis mass spectrometry (PMS) typing for $C$. difficile illustrates the usefulness of this rapid high-throughput technique. Soon after PMS apparatus was installed at the University Hospital of Wales (UHW) Public Health Laboratory, a preliminary study of PMS typing for $C$. difficile was planned, involving isolates from putative UK outbreaks retained at the Anaerobe Reference Laboratory. An outbreak of $C$. difficile-associated AAD occurred at UHW immediately before practical work commenced, and isolates from this outbreak were included in the experimental design. The initial PMS typing experiment, subsequent analyses of UHW isolates, and a blind comparison of PMS and antibiogram typing results for the outbreak isolates are described.

\section{Materials and methods}

\section{Patients}

Faecal samples from patients of the University Hospital of Wales and other Cardiff hospitals were submitted to the Department of Medical Microbiology and Public Health Laboratory, UHW. Clinical diagnosis of $C$. difficile-associated AAD or PMC was confirmed by isolation of $C$. difficile and detection of enterotoxin in the stools.

\section{Isolation procedure}

Faecal samples were cultured for $C$. difficile by the alcohol shock method. ${ }^{17}$ The deposit was inoculated on to cefoxitin-cycloserine egg yolk agar, ${ }^{18}$ and into cooked meat broth for enrichment. Isolates were identified as $C$. difficile by their characteristic pungent odour, fluorescence under UV light and lecithinase reaction, ${ }^{18}$ and with the Microscreen $C$. difficile latex agglutination diagnostic kit (Mercia Diagnostics, Guildford, Surrey). ${ }^{19}$ Toxin A (enterotoxin) was 
Table I. Monthly incidence of patients yielding their first $C$. difficile positive culture during the outbreak and post-outbreak phases

\begin{tabular}{|c|c|c|c|c|c|c|c|c|c|c|}
\hline \multirow{3}{*}{$\begin{array}{l}\text { Month for } \\
\text { 1991-92 }\end{array}$} & \multicolumn{4}{|c|}{ AG care unit } & \multirow{3}{*}{$\begin{array}{l}\text { Other } \\
\text { UHW } \\
\text { wards }\end{array}$} & \multirow{3}{*}{$\begin{array}{l}\text { Other } \\
\text { Cardiff } \\
\text { wards }\end{array}$} & \multirow{3}{*}{$\begin{array}{c}\text { Total } \\
\text { (affected) }\end{array}$} & \multirow{3}{*}{$\begin{array}{c}\text { Total } \\
\text { (unaffected) }\end{array}$} & \multirow{3}{*}{ Requests* } & \multirow{3}{*}{$\begin{array}{c}\text { Yield } \dagger \\
(\%)\end{array}$} \\
\hline & \multicolumn{2}{|c|}{$\begin{array}{l}\text { Affected } \\
\text { wards }\end{array}$} & \multicolumn{2}{|c|}{$\begin{array}{l}\text { Unaffected } \\
\text { wards }\end{array}$} & & & & & & \\
\hline & $\mathbf{A}$ & B & $\mathrm{C}$ & $\mathrm{D}$ & & & & & & \\
\hline October & 1 & 0 & 1 & 0 & 0 & 0 & 1 & 1 & $\ldots$ & .. \\
\hline November & 8 & 3 & 0 & 0 & 0 & 1 & 11 & 1 & $\dddot{90}$ & $13 \cdot 3$ \\
\hline December & 0 & 3 & 1 & 2 & 3 & 3 & 3 & 9 & 77 & $15 \cdot 6$ \\
\hline January & 2 & 5 & 3 & 0 & 3 & 1 & 7 & 7 & 129 & $9 \cdot 3$ \\
\hline February & $\overline{1}$ & 4 & 1 & 2 & 3 & 2 & 5 & 8 & 108 & $9 \cdot 3$ \\
\hline March & 5 & 0 & 0 & 1 & 1 & 3 & 5 & 5 & 131 & 6.9 \\
\hline April & 0 & 1 & 0 & 1 & 1 & 3 & 1 & 5 & 114 & $7 \cdot 0$ \\
\hline May & 1 & 0 & 0 & 0 & 0 & 4 & 1 & 4 & 100 & $5 \cdot 0$ \\
\hline June & 1 & 2 & 0 & 0 & 0 & 4 & 3 & 4 & 85 & $8 \cdot 2$ \\
\hline July & 1 & 2 & 2 & 0 & 2 & 1 & 3 & 5 & 111 & $6 \cdot 3$ \\
\hline
\end{tabular}

* Total number of requests for $C$. difficile culture during month.

$\dagger$ Total number of new patients diagnosed as a percentage of requests.

sought directly in faecal samples and in culture supernates by ELISA (Premier; Launch Diagnostics, Longfield, Kent). ${ }^{20,21}$

The first batch analysed in PMS included blind coded duplicate cultures of $C$. difficile NCTC 11207 , and 13 isolates from elsewhere in the UK stored by the Anaerobe Reference Laboratory. Ten of these isolates had been received from single units over a short time span, with some suggestion that they were from outbreaks: one set of five from Manchester, another set of two from Manchester received a year earlier and one set of three from Romford. A further three were single isolates of epidemiologically distinct origin, one from Kettering, one from St Albans and one veterinary isolate from an orang utang in Jersey. These had been stored in glycerol broth at $-70^{\circ} \mathrm{C}$ after submission for identification.

\section{PMS typing}

Single colony subcultures of $C$. difficile isolates were grown for $24 \mathrm{~h}$ at $37^{\circ} \mathrm{C}$ on Fastidious Anaerobe Agar (Lab M) in an atmosphere of $\mathrm{H}_{2} 10 \%, \mathrm{CO}_{2} 10 \%, \mathrm{~N}_{2}$ $80 \%$. Methods were as previously published. ${ }^{22}$ Briefly, colony material was sampled on a straight wire and smeared on each of four replicate pyrolysis foils. The foils were heated to $100^{\circ} \mathrm{C}$ for $10 \mathrm{~min}$ within $10 \mathrm{~min}$ of sampling and held in a vacuum desiccator before processing. Automated processing on the PYMS 200X (Horizon Instruments, Heathfield, E. Sussex) involved evacuation, Curie point pyrolysis for $4 \mathrm{~s}$ at $530^{\circ} \mathrm{C}$ and mass spectrometry of the pyrolysis products. The instrument had been upgraded since previous publications, with improvements in the stability of the electronics, the data acquisition and analysis programs, and the addition of a ring sampler, allowing uninterrupted automated processing of up to 150 foils. Data analysis was performed as previously, ${ }^{22}$ but with additional checking of the homogeneity of groups by the teaching-challenge set strategy. ${ }^{23}$ Isolates were tested in three batches: (1) to validate the method and to confirm that there was an outbreak caused by a single strain; (2) to investigate the extent of the outbreak; and (3) to assess the effectiveness of control measures and monitor post-outbreak epidemiology.

\section{Antimicrobial susceptibility patterns}

Disk susceptibility tests with chloramphenicol (Chl; $10 \mu \mathrm{g}$ ), tetracycline (Tet; $10 \mu \mathrm{g}$ ), erythromycin (Ery; $5 \mu \mathrm{g})$, vancomycin $(30 \mu \mathrm{g})$, clindamycin $(2 \mu \mathrm{g})$, rifampicin $(2 \mu \mathrm{g})$ and penicillin (1.5IU) disks were performed on DST (Oxoid) containing lysed horse blood $5 \%$, with $C$. perfringens NCTC 8237 as a control organism. Intermediate results were regarded as noncomparable, and significant inter-strain differences were found for only three antibiotics. All strains were susceptible to vancomycin and most showed intermediate susceptibility or resistance to penicillin, clindamycin and to rifampicin. Therefore, antibiograms and toxin detection results are shown in the form SIR + - indicating in this case susceptibility to $\mathrm{Chl}$, intermediate susceptibility to Tet, resistance to Ery, and toxin production in cultures but no toxin detected on direct examination of the faeces (Tox); this notation is maintained throughout the tables.

\section{Results}

\section{Description of the outbreak}

The University Hospital of Wales is an 856-bed teaching hospital with, after re-organisation of care for the elderly in September 1991, an acute geriatric (AG) care unit comprising one shared ward (A; 19 AG beds) and three full wards (B, C and D; 33, 33 and 29 beds, respectively). Isolation rates for $C$. difficile in the hospital were $c .1 /$ month before October 1991. Three AG patients on the shared ward (A) developed diarrhoea during 2 weeks of October-November 1991; each had been hospitalised for between 18 and 34 days. Two further patients developed AAD during the subsequent week, one on ward $A$ and another on ward 


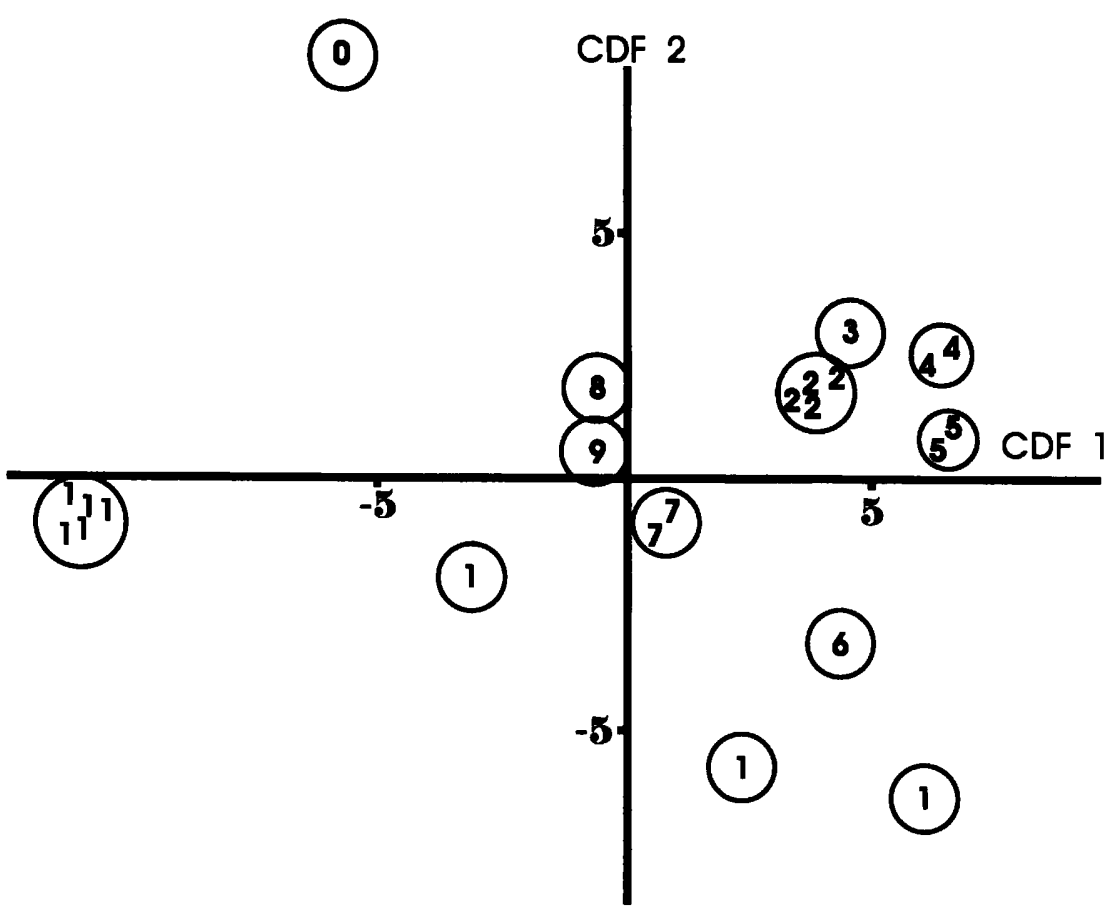

Fig. 1. A representation of the extent of statistically significant differences between isolates in PMS analyses of batch 1 as a scattergram of isolate points. The distance between strain points indicates the level of dissimilarity between the strains. The diagram illustrates $c .52 \%$ of the differences on the first two canonical discriminant functions (CDFs). Further information on individual Cardiff isolates is presented in table II. Isolate origins are: 1, Cardiff; 2, Manchester; 3, Manchester (outlier); 4, duplicate spectra of NCTC 11207; 5, Manchester (earlier outbreak); 6, Romford (outlier); 7, Romford; 8, Kettering; 9, St Albans; 0, Jersey (veterinary).

Table II. PMS and antibiogram results for the local isolates of batch 1

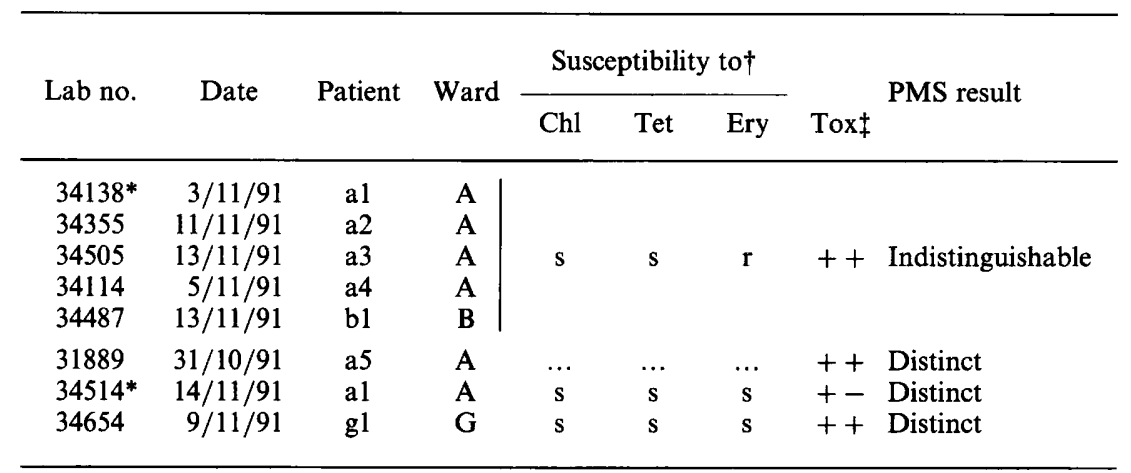

\footnotetext{
* Isolate series from a single patient (a1) containing distinct strains.

$\dagger$ Chl, chloramphenicol; Tet, tetracycline; Ery, erythromycin; ..., no susceptibility results were available for isolate 31889 .

\$ Toxin production, in culture and in faeces.
}

B. One infected patient had been transferred temporarily from ward A to ward B early after the onset of AAD. C. difficile was isolated from, and toxin A was detected in, faecal specimens.

Faecal specimens were obtained from all AG patients on the unit, whether symptomatic or not, and C. difficile was found in specimens from 11 patients during November (eight in ward A, three in ward B; table I), only half of whom were recorded as having diarrhoeal symptoms. Advice on the need for strict handwashing was given to the staff on wards A and B, and the clinicians were advised to restrict antibiotic usage throughout the AG care unit. Standards of ward cleaning were improved.

The number of new patients yielding $C$. difficile fell during December, and no further patients were found to be $C$. difficile-positive on ward A (table I). During
January 1992, the general rate of isolation in the AG care unit increased again; this was paralleled by increased rates of isolation in other wards and units elsewhere in the city. Further inspections revealed that standards of cleaning had fallen over the Christmas period, and it was notable that the ward worst affected (B) was that where rates of isolation of $C$. difficile were highest. Rates remained high in February, but returned to pre-outbreak levels in April.

\section{PMS typing}

The findings of Batch 1 (fig. 1) demonstrated that: (i) isolates from purported earlier outbreaks in the UK tended to cluster as distinct source-related groups; (ii) there was a clear cluster of five isolates from the AG care unit, indistinguishable in PMS; and (iii) three 


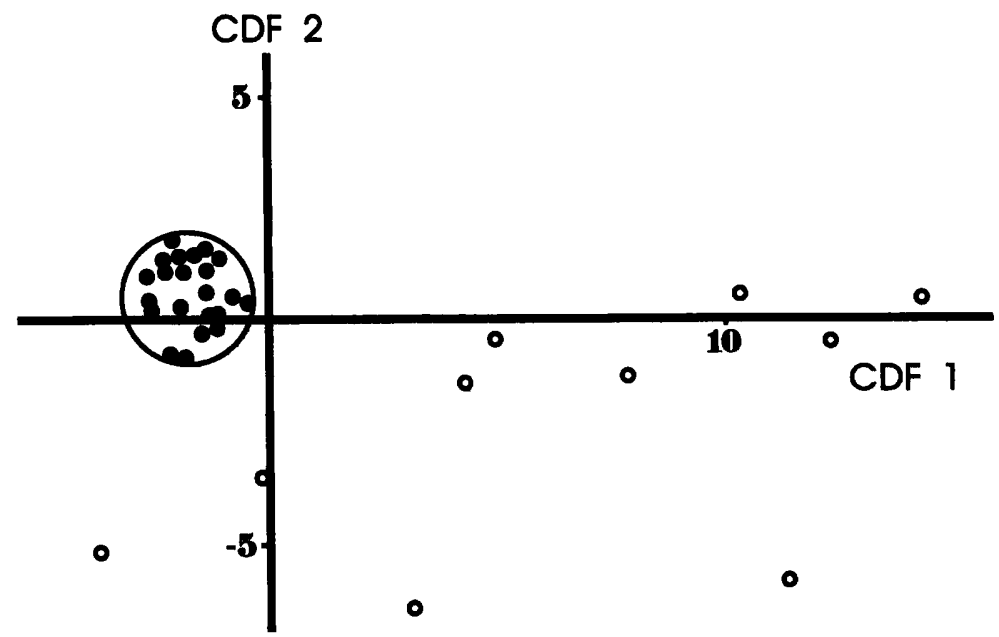

Fig. 2. A representation of the extent of statistically significant differences between isolates in PMS analysis of batch 2 . The diagram illustrates c. $74 \%$ of significant differences. Points representing isolates that were indistinguishable in PMS are circled. Further information on individual isolates is presented in table III.

Table III. PMS and antibiogram results for the isolates of batch 2

\begin{tabular}{|c|c|c|c|c|c|c|c|c|c|}
\hline \multirow{2}{*}{ Lab no. } & \multirow{2}{*}{ Date } & \multirow{2}{*}{ Patient } & \multirow{2}{*}{ Ward } & \multicolumn{3}{|c|}{ Susceptibility to } & \multirow{2}{*}{\multicolumn{2}{|c|}{ Tox }} & \multirow{2}{*}{ PMS result } \\
\hline & & & & Chl & Tet & Ery & & & \\
\hline *34138† & $3 / 11 / 91$ & a1 & $\mathbf{A}$ & & & & & +1 & \\
\hline $34355 \dagger$ & $11 / 11 / 91$ & $\mathrm{a} 2$ & A & & & & & + & \\
\hline $34505 \dagger$ & $13 / 11 / 91$ & a3 & $\mathbf{A}$ & & & & & + & \\
\hline 34707 & $17 / 11 / 91$ & a3 & $\mathrm{A}$ & & & & & + & \\
\hline 36077 & $21 / 11 / 91$ & a3 & A & & & & & - & \\
\hline 36085 & $22 / 11 / 91$ & a3 & A & & & & & - & \\
\hline $34114 \uparrow$ & $5 / 11 / 91$ & a4 & A & & & & & + & \\
\hline 34666 & $15 / 11 / 91$ & a6 & A & & & & & + & \\
\hline 34853 & $18 / 11 / 91$ & a6 & A & & & & & + & \\
\hline 36086 & $22 / 11 / 91$ & a6 & A & & & & & + & \\
\hline 34667 & $15 / 11 / 91$ & a7 & A & & & & & + & \\
\hline 34834 & $18 / 11 / 91$ & a7 & A & & & & & + & \\
\hline 34885 & $18 / 11 / 91$ & a8 & A & s & $\mathbf{s}$ & $r$ & + & + & Indistinguishable \\
\hline 36047 & $20 / 11 / 91$ & a9 & A & & & & & - & \\
\hline $34487 \dagger$ & $13 / 11 / 91$ & b1 & $\mathbf{B}$ & & & & & + & \\
\hline 34692 & $14 / 11 / 91$ & bl & B & & & & & + & \\
\hline 36386 & $28 / 11 / 91$ & $\mathrm{~b} 2$ & B & & & & & - & \\
\hline 36916 & $9 / 12 / 91$ & b3 & B & & & & & - & \\
\hline 39192 & $13 / 12 / 91$ & b3 & B & & & & & + & \\
\hline 39497 & $20 / 12 / 91$ & b4 & B & & & & & - & \\
\hline 36885 & $9 / 12 / 91$ & d1 & D & & & & & - & \\
\hline 36603 & $3 / 12 / 91$ & $\mathrm{~d} 2$ & D & & & & & - & \\
\hline 36920 & $9 / 12 / 91$ & f1 & $F$ & & & & & + & \\
\hline 39511 & $23 / 12 / 91$ & i1 & I & & & & & $1-\mid$ & \\
\hline$* 34514 \dagger$ & $14 / 11 / 91$ & a1 & A & $\mathrm{s}$ & s & s & + & - & Distinct \\
\hline 36047 & $21 / 11 / 91$ & b5 & B & $\mathrm{i}$ & $\mathbf{r}$ & $r$ & - & - & Distinct \\
\hline 39169 & $13 / 12 / 91$ & b6 & B & $\mathbf{r}$ & s & $\mathbf{r}$ & + & + & Distinct \\
\hline 39590 & $28 / 12 / 91$ & d3 & D & $\mathrm{s}$ & $\mathrm{s}$ & $\mathbf{r}$ & + & - & Distinct \\
\hline 39050 & $11 / 12 / 91$ & d4 & D & $\mathrm{s}$ & $\mathbf{s}$ & $\mathbf{s}$ & + & + & Distinct \\
\hline$\ddagger 34603$ & $14 / 11 / 91$ & el & $\mathrm{E}$ & $\mathrm{s}$ & $\mathrm{s}$ & s & + & + & Distinct \\
\hline$\ddagger 34631$ & $15 / 11 / 91$ & e1 & $\mathrm{E}$ & $\mathrm{r}$ & s & $\mathrm{i}$ & + & + & Distinct \\
\hline $34654 \dagger$ & $9 / 11 / 91$ & g1 & $\mathrm{G}$ & s & $\mathrm{s}$ & s & + & + & Distinct \\
\hline 39089 & $10 / 12 / 91$ & h1 & $\mathrm{H}$ & $\mathbf{s}$ & $\mathbf{s}$ & s & - & - & Distinct \\
\hline 39554 & $23 / 12 / 91$ & i2 & I & s & $\mathbf{s}$ & $\mathbf{r}$ & + & + & Distinct \\
\hline
\end{tabular}

Abbreviations as for table II.

* $\ddagger$ Isolate series from single patients $(*, a 1 ; \ddagger, \mathrm{e})$ containing distinct strains.

+ Isolates were included in batch 1 .

further isolates from the AG care unit and elsewhere in the city were clearly distinct from one another and from all other isolates examined.

The results of this blind PMS trial were supported by antibiogram typing of the UHW isolates (table II). One isolate (31889) had been lost on subculture, and antibiotic susceptibility tests could not be performed. This was particularly unfortunate as this isolate was from the supposed index case, but it had been found to be distinct in PMS. Two isolates from a single patient (a1) were distinct in PMS and antibiogram typing. The combined data of PMS, antibiogram typing and the 


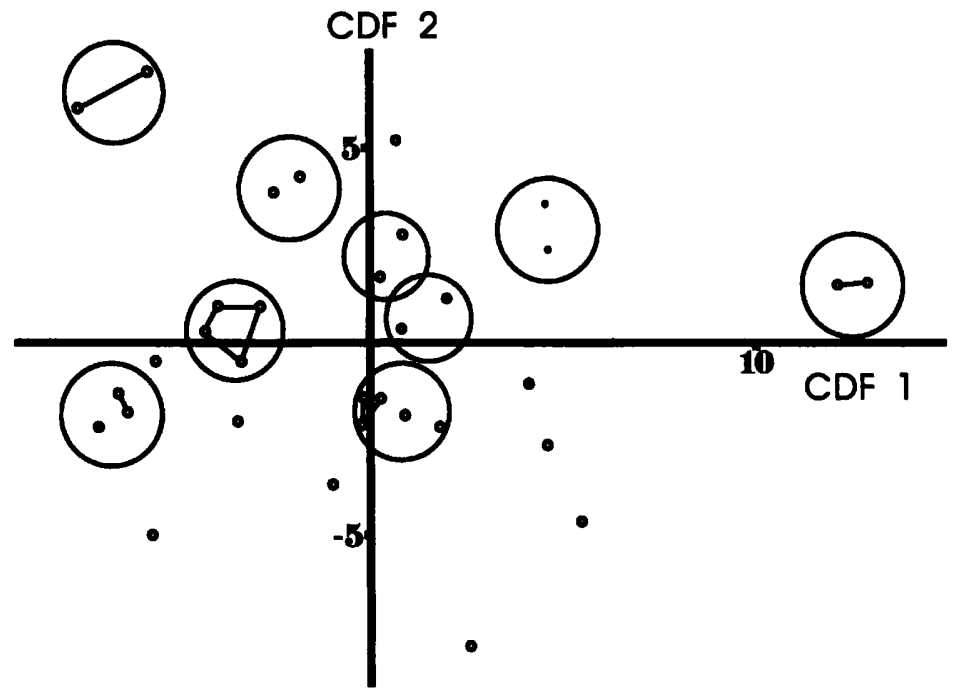

Fig. 3. A representation of the extent of statistically significant differences between isolates in PMS analysis of batch 3. The diagram illustrates c. $49 \%$ of significant differences. Points representing indistinguishable serial isolates from the same patient are joined by lines. Further information on individual isolates is presented in table IV.

Table IV. PMS and antibiogram results for the isolates of batch 3

\begin{tabular}{|c|c|c|c|c|c|c|c|c|}
\hline \multirow{2}{*}{ Lab no. } & \multirow{2}{*}{ Date } & \multirow{2}{*}{ Patient } & \multirow{2}{*}{ Ward } & \multicolumn{3}{|c|}{ Susceptibility to } & \multirow[b]{2}{*}{ Tox } & \multirow{2}{*}{ PMS result } \\
\hline & & & & $\mathrm{Chl}$ & Tet & Ery & & \\
\hline $\begin{array}{r}* 54 \\
* 458\end{array}$ & $\begin{array}{r}3 / 11 / 92 \\
15 / 01 / 92\end{array}$ & $\begin{array}{l}\mathrm{d} 3 \\
\mathrm{~d} 3\end{array}$ & $\begin{array}{l}\text { D } \\
\text { D }\end{array}$ & $\begin{array}{l}\mathrm{s} \\
\mathrm{s}\end{array}$ & $\begin{array}{l}\mathbf{s} \\
\mathbf{s}\end{array}$ & $\begin{array}{l}r \\
r\end{array}$ & $\begin{array}{l}+-1 \\
+-1\end{array}$ & Indistinguishable \\
\hline $\begin{array}{l}349 \\
591 \\
523\end{array}$ & $\begin{array}{l}12 / 01 / 92 \\
20 / 01 / 92 \\
17 / 01 / 92\end{array}$ & $\begin{array}{l}\text { a10 } \\
\text { a10 } \\
\text { b7 }\end{array}$ & $\begin{array}{l}\text { A } \\
\text { A } \\
\text { B }\end{array}$ & $\begin{array}{l}\mathrm{s} \\
\mathrm{s} \\
\mathrm{s}\end{array}$ & $\begin{array}{l}\mathrm{s} \\
\mathrm{s} \\
\mathrm{s}\end{array}$ & $\begin{array}{l}\mathrm{s} \\
\mathrm{s} \\
\mathrm{s}\end{array}$ & $\begin{array}{l}+- \\
+- \\
++\end{array}$ & Indistinguishable \\
\hline $\begin{array}{l}789 \\
841 \\
927 \\
953\end{array}$ & $\begin{array}{l}27 / 01 / 92 \\
28 / 01 / 92 \\
30 / 01 / 92 \\
31 / 01 / 92\end{array}$ & $\begin{array}{l}\text { a11 } \\
\text { a11 } \\
\text { a11 } \\
\text { a11 }\end{array}$ & $\begin{array}{l}\text { A } \\
\text { A } \\
\text { A } \\
\text { A }\end{array}$ & $\begin{array}{l}\mathrm{s} \\
\mathrm{s} \\
\mathrm{s} \\
\mathrm{s}\end{array}$ & $\begin{array}{l}\mathrm{s} \\
\mathrm{s} \\
\mathrm{s} \\
\mathrm{s}\end{array}$ & $\begin{array}{l}r \\
r \\
r \\
r\end{array}$ & $\begin{array}{l}++ \\
+- \\
t- \\
+-\end{array}$ & Indistinguishable \\
\hline $\begin{array}{r}446 \\
\ddagger 159\end{array}$ & $\begin{array}{r}14 / 01 / 92 \\
6 / 01 / 92\end{array}$ & $\begin{array}{l}\text { b8 } \\
\text { b9 }\end{array}$ & $\begin{array}{l}\text { B } \\
\text { B }\end{array}$ & $\begin{array}{l}\mathrm{s} \\
\mathrm{s}\end{array}$ & $\mathrm{i}$ & $\begin{array}{l}r \\
r\end{array}$ & $\begin{array}{l}++ \\
++\end{array}$ & Indistinguishable \\
\hline $\begin{array}{r}\$ 335 \\
720\end{array}$ & $\begin{array}{l}11 / 01 / 92 \\
23 / 01 / 92\end{array}$ & $\begin{array}{l}\text { b9 } \\
\text { e2 }\end{array}$ & $\begin{array}{l}\mathrm{C} \\
\mathrm{E}\end{array}$ & $\begin{array}{l}\mathrm{s} \\
\mathrm{s}\end{array}$ & $\begin{array}{l}\mathrm{s} \\
\mathrm{s}\end{array}$ & $\begin{array}{l}r \\
r\end{array}$ & $\begin{array}{l}+- \\
++\end{array}$ & Indistinguishable \\
\hline $\begin{array}{l}334 \\
762 \\
421 \\
696 \\
794\end{array}$ & $\begin{array}{l}11 / 01 / 92 \\
24 / 01 / 92 \\
14 / 01 / 92 \\
23 / 01 / 92 \\
24 / 01 / 92\end{array}$ & $\begin{array}{l}\mathrm{b} 10 \\
\mathrm{e} 3 \\
\mathrm{cl} \\
\mathrm{cl} \\
\mathrm{cl}\end{array}$ & $\begin{array}{l}\mathrm{B} \\
\mathrm{E} \\
\mathrm{C} \\
\mathrm{C} \\
\mathrm{C}\end{array}$ & $\begin{array}{l}\mathrm{s} \\
\mathrm{s} \\
\mathrm{s} \\
\mathrm{s} \\
\mathrm{s}\end{array}$ & $\begin{array}{l}\mathrm{s} \\
\mathrm{s} \\
\mathrm{s} \\
\mathrm{s} \\
\mathrm{s}\end{array}$ & $\begin{array}{l}\mathrm{r} \\
\mathrm{r} \\
\mathrm{r} \\
\mathrm{r} \\
\mathrm{r}\end{array}$ & $\begin{array}{l}++ \\
+- \\
++ \\
++ \\
++\end{array}$ & Indistinguishable \\
\hline $\begin{array}{c}36077 \dagger \\
338\end{array}$ & $\begin{array}{l}21 / 11 / 91 \\
11 / 01 / 92\end{array}$ & $\begin{array}{l}\mathrm{a} 4 \\
\mathrm{~b} 11\end{array}$ & $\begin{array}{l}\text { A } \\
\text { B }\end{array}$ & $\begin{array}{l}\mathrm{s} \\
\mathrm{s}\end{array}$ & $\begin{array}{l}\mathrm{s} \\
\mathrm{s}\end{array}$ & $\begin{array}{l}\mathrm{r} \\
\mathrm{r}\end{array}$ & $\begin{array}{l}+-1 \\
+-1\end{array}$ & Indistinguishable \\
\hline $\begin{array}{r}\$ 93 \\
\$ 470\end{array}$ & $\begin{array}{r}6 / 01 / 92 \\
15 / 01 / 92\end{array}$ & $\begin{array}{l}\mathrm{c} 2 \\
\mathrm{c} 2\end{array}$ & $\begin{array}{l}\mathrm{C} \\
\mathrm{C}\end{array}$ & $\begin{array}{l}\mathrm{s} \\
\mathrm{s}\end{array}$ & $\begin{array}{l}\mathrm{s} \\
\mathrm{s}\end{array}$ & $\begin{array}{l}r \\
r\end{array}$ & $\begin{array}{l}++ \\
+-1\end{array}$ & Indistinguishable \\
\hline $\begin{array}{l}628 \\
864\end{array}$ & $\begin{array}{l}21 / 01 / 92 \\
29 / 01 / 92\end{array}$ & $\begin{array}{c}\mathrm{g} 2 \\
\text { all }\end{array}$ & $\begin{array}{l}G \\
G\end{array}$ & $\begin{array}{l}\mathrm{s} \\
\mathrm{s}\end{array}$ & $\begin{array}{l}\mathrm{s} \\
\mathrm{s}\end{array}$ & $\begin{array}{l}\mathrm{r} \\
\mathrm{r}\end{array}$ & $\begin{array}{l}+ \\
+\end{array}$ & Indistinguishable \\
\hline $\begin{array}{r}478 \\
* 539\end{array}$ & $\begin{array}{l}14 / 01 / 92 \\
17 / 01 / 92\end{array}$ & $\begin{array}{l}\mathrm{i} 3 \\
\mathrm{~d} 3\end{array}$ & $\begin{array}{l}\text { I } \\
\text { D }\end{array}$ & $\begin{array}{l}\mathrm{s} \\
\mathrm{s}\end{array}$ & $\begin{array}{l}\mathrm{s} \\
\mathrm{r}\end{array}$ & $\begin{array}{l}r \\
r\end{array}$ & $-\overline{+}$ & $\begin{array}{l}\text { Distinct } \\
\text { Distinct }\end{array}$ \\
\hline *976 & $1 / 01 / 92$ & d3 & D & $\mathrm{s}$ & s & $\mathrm{r}$ & $\begin{array}{l}++ \\
+-\end{array}$ & Distinct \\
\hline 321 & $11 / 01 / 92$ & c3 & $\mathrm{C}$ & $\mathrm{s}$ & s & $\mathrm{s}$ & +- & Distinct \\
\hline 144 & $6 / 01 / 92$ & g2 & G & $\mathrm{s}$ & $\mathrm{r}$ & $\mathbf{s}$ & ++ & Distinct \\
\hline 627 & $21 / 01 / 92$ & g3 & $\mathrm{G}$ & $\mathrm{s}$ & s & s & + & Distinct \\
\hline 986 & $4 / 02 / 92$ & b12 & B & s & $\mathrm{s}$ & $\mathrm{r}$ & ++ & Distinct \\
\hline$\$ 320$ & $11 / 01 / 92$ & c2 & $\mathrm{C}$ & $\mathbf{s}$ & $\mathbf{s}$ & $\mathrm{r}$ & ++ & Extreme outlier \\
\hline
\end{tabular}

Abbreviations as for table II.

$* \ddagger \S$ Isolate series from single patients $\left({ }^{*}, \mathrm{~d} 3 ; \ddagger, \mathrm{b} 9 ; \S, \mathrm{c} 2\right)$ containing distinct strains.

$\dagger$ Strain 36077 was a representative isolate of the outbreak strain from batch 2 .

epidemiology provided support for the hypothesis that a single strain outbreak of cross-infection was occurring, accompanied by a few independent sporadic infections.
Batch 2, analysed in early January, included the surviving seven local isolates examined in batch 1 and a further 27 local isolates. In blinded trials, PMS results and antibiograms agreed once more (fig. 2, 
table III), showing a core of indistinguishable isolates, with a minority of distinct strains, mostly from wards other than those of the AG care unit. The group membership for the seven re-examined isolates was identical to that found previously. One notable feature was that two patients (al and el) gave serial isolates that were distinct in PMS and antibiograms; for one patient (a1) these were isolated within a 36-h period. Only one of these isolates (from a1) was indistinguishable from the outbreak strain. These results confirmed those of batch 1 .

Again the evidence was of a single strain outbreak centred on two wards (A and B). Only four isolates from other wards or units were indistinguishable from the outbreak strain. For three of these, the patients had been transferred from, or re-admitted after, a stay on one of the affected wards. Of the 10 isolates found to be distinct from the outbreak strain, only three were isolated from patients on wards A and B. These appeared to be part of a background incidence of independent sporadic infections. This retrospective survey confirmed the conclusions of the first trial. The outbreak had clearly subsided by early December, with minimal incidence on the two affected wards.

The rising incidence of $C$. difficile isolation in January 1992 suggested that the outbreak had become re-established, although awareness of the AAD problem had prompted an increased rate of requests for $C$. difficile culture (table I). Therefore, a third batch of 32 local isolates was typed in early February 1992. This included one isolate (36077), representative of the outbreak strain, from batch 2. The PMS results (fig. 3, table IV) were in marked contrast to those of the previous batches. There was no major group of indistinguishable isolates, but rather a scatter of distinct single strains and small groups of two-to-five isolates, mainly comprising serial isolates from single patients. Equally striking was the failure of antibiogram typing to distinguish between many of the isolates found to be distinct in PMS. Only one isolate (338) appeared indistinguishable from the outbreak strain (represented by isolate 36077) in PMS

One patient $(\mathrm{d} 3)$ yielded four sequential isolates, three of which were distinct in PMS, with two distinct antibiogram patterns; one patient (b9) yielded two sequential isolates distinct in PMS, with slight evidence of differences in antibiograms; and one patient (c2) yielded three sequential isolates, one of which was distinct in PMS, but not in antibiograms.

Although the antibiogram results did not distinguish many of the isolates of this batch judged distinct in PMS, there was little epidemiological evidence of a continuing single strain outbreak. There was no clear focus of increased incidence on a single ward (table I), and the parallel rise in incidence on other units seemed to indicate a common background trend, that had begun to rise in December in other units. Our conclusion was that the outbreak had not recurred. It seemed likely that the increased isolation rate was due to a combination of two factors-increased awareness and investigation, and a possible seasonal change in the number of AG patients rendered susceptible to AAD by antibiotic treatment for respiratory complaints. No action was taken, and the ensuing fall in isolation rates supported our conclusions.

\section{Discussion}

Antibiograms were informative initially, indicating the possibility of a developing outbreak, but they gave less resolution than PMS, as was evident in the postoutbreak phase, when they provided little strain discrimination. However, this is a simple technique, available to any laboratory, whose use is indicated whenever an outbreak is suspected. It is an appropriate preliminary screen to filter out clearly unrelated strains when isolates are referred for typing. PMS provided a simple, rapid and inexpensive method of typing these isolates. The hasty shift from method development to successful routine use, forced by circumstances, emphasises the ease with which PMS can be adapted to new species as noted elsewhere. ${ }^{22}$ The conclusions from the PMS analyses were clearly supported by epidemiological evidence.

The results for the stored UK isolates of batch 1, and for the comparison of PMS and antibiogram results in all three batches of UHW isolates, offered strong evidence for the reliability of PMS discrimination. Further evidence is now available from other PMS studies. ${ }^{16,24}$ Results for isolates from another AAD outbreak investigated in PMS and in two independent SDS-PAGE studies showed broad agreement. ${ }^{25}$

However, for five patients of the 40 investigated in typing, multiple distinct strains were isolated from a single patient over short time spans, indicating that a patient might be concurrently infected with multiple strains of $C$. difficile. This has been observed elsewhere, ${ }^{26}$ and could present problems in typing. $C$. difficile has a pleomorphic colonial morphology that removes any possibility of detecting mixed strains, other than by typing multiple picks from the original isolation plate. Strain mixtures could also be a source of confusion in comparative trials of $C$. difficile typing methods.

Laboratories where diagnosis rests solely on detection of toxin in faeces, with no attempt to isolate the organism, are clearly at a disadvantage in a possible outbreak situation. With no isolates to submit for typing, by whatever method, it is difficult to distinguish between a simple rise in the incidence of independent sporadic infections, and a single strain outbreak. We strongly recommend that laboratories employ isolation and toxin detection methods in routine investigation of AAD.

The results also indicate that it is unnecessary to type large numbers of isolates in an outbreak. The key finding in this outbreak was that five of the eight isolates analysed in batch 1 were indistinguishable, 
and all active measures flowed from this early result. Our conclusions from batch 3 would have been similar had we typed 10 isolates from any set of 10 patients. Considered selection of small numbers of isolates for typing, rather than every isolate found, has many merits, not least that reference laboratories are likely to return an early result for a manageable workload.

Many key questions about $C$. difficile have yet to be answered. The initial sources of outbreak strains are unknown and there is little data on carriage frequency in the population at risk. The background incidence of $C$. difficile in the hospital environment is unknown, although it appears to increase during outbreaks. ${ }^{27,28}$ Our results hint at an underlying seasonal variation in incidence, which may correlate with the increased rates of admission for respiratory infections during the autumn and winter.

Our tentative conclusions from analysis of this and

\section{References}

1. Bartlett JG, Chang TW, Gurwith M, Gorbach SL, Onderdonk AB. Antibiotic-associated pseudomembranous colitis due to toxin-producing clostridia. $N$ Engl J Med 1978; 298 : 531-534.

2. Larson HE, Price AB, Honour P, Borriello SP. Clostridium difficile and the aetiology of pseudomembranous colitis. Lancet 1978; 1 : 1063-1066.

3. MacFarland LV, Mulligan ME, Kwok RYY, Stamm MS, Stamm WE. Nosocomial acquisition of Clostridium difficile infection. $N$ Engl J Med 1989; 320: 204-210.

4. Bender BS, Laughon BE, Gaydos C et al. Is Clostridium difficile endemic in chronic-care facilities? Lancet 1986; 2: 11-13.

5. Riley TV, Bowman RA, Carroll SM. Diarrhoea associated with Clostridium difficile in a hospital population. Med J Aust $1983 ; 1$ : 166-169.

6. Communicable Diseases Report, PHLS Communicable Disease Surveillance Centre, 1992; 2: 9.

7. Johnson S, Clabots CR, Linn FV, Olson MM, Peterson LR, Gerding DN. Nosocomial Clostridium difficile colonisation and disease. Lancet 1990; 336: 97-100.

8. Delmée M, Laroche Y, Avesani V, Cornelis G. Comparison of serogrouping and polyacrylamide gel electrophoresis for typing Clostridium difficile. J Clin Microbiol 1986; 24: 991-994.

9. Tabaqchali S, Holland D, O'Farrell S, Silman R. Typing scheme for Clostridium difficile: its application in clinical and epidemiological studies. Lancet 1984; 1 : 935-938.

10. Tabaqchali S, O'Farrell S, Holland D, Silman R. Method for the typing of Clostridium difficile based on polyacrylamide gel electrophoresis of $\left[{ }^{35} \mathrm{~S}\right]$ methionine-labelled proteins. $J$ Clin Microbiol 1986; 23: 197-198.

11. Poxton IR, Byrne MD. Immunological analysis of the EDTAsoluble antigens of Clostridium difficile and related species. $J$ Gen Microbiol 1981; 122 : 41-46.

12. Delmée M, Homel M, Wauters G. Serogrouping of Clostridium difficile strains by slide agglutination. I Clin Microbiol 1985; 21 : 323-327.

13. Sell TL, Schaberg DR, Fekety FR. Bacteriophage and bacteriocin typing scheme for Clostridium difficile. J Clin Microbiol 1983; 17: 1148-1152.

14. Peerbooms PGH, Kuijt P, Maclaren DM. Application of chromosomal restriction endonuclease digest analysis for use as a typing method for Clostridium difficile. J Clin Pathol 1987; 40: 771-776.

15. Burdon DW. Clostridium difficile: The epidemiology and prevention of hospital-acquired infection. Infection 1982; 10: $203-204$.

16. Cartmill TDI, Orr K, Freeman R, Sisson PR, Lightfoot NF. other outbreaks is that initial sporadic cases occur in antibiotic-treated patients, presumably due to autoinfection in carriers. A break in hygienic precautions then allows spread among susceptible hosts, in which the most infective of the sporadic strains rapidly becomes predominant. Antibiotic control and measures to prevent faecal-environmental-oral spread appeared effective in this incident as they have in others. ${ }^{28,29}$

C. difficile is an opportunist pathogen that requires extraneous influences to cause overt infection, but can spread rapidly in a susceptible population. It is an enteric pathogen, but there is little evidence that it is food-borne, and its ability to sporulate opens potential pathways for spread that the common enteric pathogens cannot exploit. The availability of highthroughput typing methods is essential for the investigation of the epidemiology of this organism.

Nosocomial infection with Clostridium difficile investigated by pyrolysis mass spectrometry. J Med Microbiol 1992; 37 : 352-356.

17. Borriello SP, Honour P. Simplified procedure for the routine isolation of Clostridium difficile from faeces. J Clin Pathol $1981 ; 34$ : 1124-1127.

18. Brazier JS. The role of the laboratory in investigations of Clostridium difficile diarrhoea. Clin Infect Dis 1993: in press.

19. Bowman RA, Arrow SA, Riley TV. Latex particle agglutination for detecting and identifying Clostridium difficile. $J$ Clin Pathol 1986; 39: 212-214.

20. De Girolami PC, Hanff PA, Eichelberger K et al. Multicenter evaluation of a new enzyme immunoassay for detection of Clostridium difficile enterotoxin A. J Clin Microbiol 1992; 30: 1085-1088.

21. Borriello SP, Vale T, Brazier JS, Hyde S, Chippeck E. Evaluation of the Premier enzyme immunoassay kit for the detection of Clostridium difficile toxin A. Eur $J$ Clin Microbiol Infect Dis 1992; 11: 360-363.

22. Magee JT, Hindmarch JM, Burnett IA, Pease A. Epidemiological typing of Streptococcus pyogenes by pyrolysis mass spectrometry. J Med Microbiol 1989; 30: 273-278.

23. Hindmarch JM, Magee JT, Hadfield MA, Duerden BI. A pyrolysis-mass spectrometry study of Corynebacterium spp. J Med Microbiol 1990; 31: 137-149.

24. Magee JT, Brazier JS, Duerden BI, Ribeiro CD. Pyrolysis mass spectrometry (PMS) of Clostridium difficile isolates from two outbreaks of antibiotic-associated diarrhoea. $J \mathrm{Med}$ Microbiol 1992; 37 Suppl 1: Abstract 278.

25. Brazier JS, Magee JT, Riley H, Costas M. Comparison of SDSPAGE and pyrolysis mass spectrometry typing results for Clostridium difficile. In: Medical and dental aspects of anaerobes. Duerden BI, Brazier JS, Wade W (eds) Cardiff, Society for Anaerobic Microbiology. (in press).

26. O'Neill GL, Beaman MH, Riley TV. Relapse versus reinfection with Clostridium difficile. Epidemiol Infect 1991; 107: 627-635.

27. Fekety R, Kim KH, Brown D, Batts DH, Cadmore M, Silva J. Epidemiology of antibiotic-associated colitis: isolation of Clostridium difficile from the hospital environment. $\mathrm{Am} \mathrm{J}$ Med 1981; 70: 906-908.

28. Kim KH, Fekety R, Batts DH et al. Isolation of Clostridium difficile from the environment and contacts of patients with antibiotic-associated colitis. J Infect Dis 1981; 143: 42-50.

29. Malamou-Ladas H, O'Farrell S, Nash JQ, Tabaqchali, S. Isolation of Clostridium difficile from patients and the environment of hospital wards. J Clin Pathol 1983; 36: 88-92. 